\title{
Secrecy on cost of publicly funded hep C treatment
}

Cite as: CMAJ 2017 April 24;189:E617-8. doi: 10.1503/cmaj.1095412

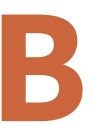

ritish Columbia's public drug plan expanded access to four new, expensive, hepatitis $C$ drugs on March 21, following a similar decision by Ontario's public drug plan February 28.

But even as hepatitis treatment experts cheered this expansion, several decry the lack of transparency about the costs of these taxpayer-funded drugs.

The expansion means drugs are now available for patients with early-stage fibrosis who are co-infected with HIV, or hepatitis $\mathrm{B}$, or who have chronic kidney disease. Starting in 2019, BC will cover all patients with hepatitis $C$, regardless of the type or severity.

The new generation of direct-acting hepatitis $C$ antivirals work in three months or less, and have the ability to clear the virus in over $95 \%$ of patients.

However, the drugs' list prices range from $\$ 45000$ to more than $\$ 100000$ per fully-treated patient, according to the pan-Canadian Pharmaceutical Alliance ( $\mathrm{pCPA}$ ), which negotiates drug prices on behalf of five federal drug plans and 13 provincial and territorial plans. The World Hepatitis Alliance estimates Australia pays $\$ 16000$ per patient treated for hepatitis C.

Public spending on prescription drugs across Canada increased $9.2 \%$ in 2015; almost two-thirds of that growth was due to the introduction of two hepatitis C drugs (Harvoni and Sovaldi), according to the Canadian Institute for Health Information.

The expanded list of drugs in $B C$ and Ontario was announced after three drug makers, Gilead Sciences Canada, Merck Canada, and Bristol-Myers Squibb Canada, agreed to reduce previously negotiated prices for Harvoni and Sovaldi, and lower the cost of new additions: Daklinza,

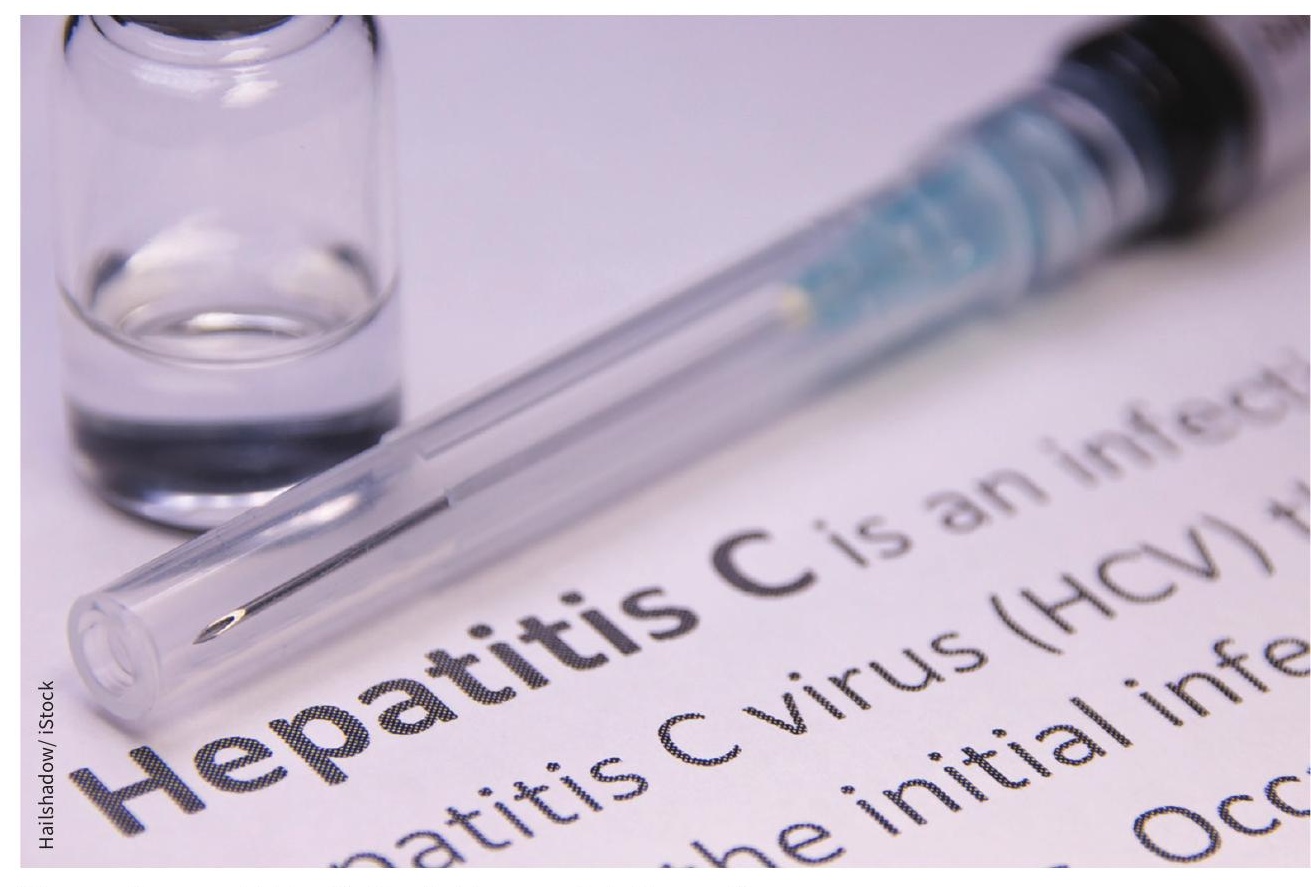

The new drugs are highly effective, but how much do they cost?

Epclusa, Sunvepra and Zepatier. It is not clear if other provinces will follow $B C$ and Ontario's lead to expand access. An estimated 250000 people in Canada have hepatitis C.

This agreement makes the drugs "more affordable," says PCPA senior manager Imran Al. However, the detailed terms of the agreement are confidential.

In responses to CMAJ requests filed under the federal Access to Information Act, Correctional Service of Canada and Health Canada likewise refused to provide information about the cost of the drugs.

Officials at the three drug makers referred CMAJ's requests for interviews to Innovative Medicines Canada (IMC), an Ottawa-based lobby group for brandname drug makers.

"Keeping these agreements confidential enables manufacturers to lower prices for public plans and the vulnerable Canadians they serve," IMC media relations director Sarah Dion-Marquis says.

The secrecy around the public cost of hepatitis drugs in Canada concerns some advocates, clinicians and researchers.

Adam Cook is the hepatitis program manager at the Canadian Treatment Action Council and an executive committee member at Action Hepatitis Canada, a patient advocacy group. "While the expansion in treatment is very welcome news," he says, "the fact that the real costs of these drugs paid by taxpayers is inside a black box has the potential to hurt the quality of medical care, and denies transparency in public health expenditures."

Dr. Morris Sherman, chairperson of the Canadian Liver Foundation's board of directors, and Dr. Jordan Feld, a clinician- 
scientist at the Toronto Western Hospital Liver Clinic, agree with Cook.

"As a prescriber, it's important to know the costs of the drugs," says Feld. "The pCPA should give us much more transparency. Prescribers should be partners in maximizing the public good. I care about knowing what volume of prescriptions minimizes the price."
In Halifax, Dr. Lisa Barrett, principal investigator for the Senescence, Aging and Infection and Immunity Laboratory at Dalhousie University, is concerned that secret drug price negotiations are creating "a framework for health policy with almost no input from medical experts."

"We should not allow manufacturers to force this level of secrecy," says Steven
Morgan, director of the University of British Columbia's Centre for Health Services and Policy Research. "We need to raise the level of discussion about drug pricing transparency. At the very least, clinicians deserve to know when the contracts involve price-volume reductions."

Paul Webster, Toronto, Ontario 